\title{
Already Dead? Of Tombstones, Empire, and Photography
}

Jeremy F. Walton

\section{Introduction: On Visualizing Empire}

Across the segmented political space of central and south-east Europe, cemeteries speak eloquently of the foreclosed social, religious, and political pasts of empire to those attuned to their vocabulary and cadences. In this essay, I highlight neglected temporalities of past empires by foregrounding the ambivalent temporality of photography. I offer a collage of photographs from four post-imperial cemeteries: the Zeitenlik Allied War Cemetery in Thessaloniki, Greece; Mirogoj Cemetery in Zagreb, Croatia; the Imperial and Royal Habsburg Naval Cemetery in Pula, Croatia; and the Soldatenfriedhof in Styria, Austria. I do so with two aims. First, I explore how tombstones form a serendipitous archive of empire's social worlds in sepulchral form. Secondly, based on this consideration, I ruminate on the photography of tombstones generally. With Roland Barthes's famous aphorism on the deathly quality of photography in mind-"by attesting that the object has been real, the photograph surreptitiously induces belief that it is alive ... but by shifting this reality to the past ('this-has-been'), the photograph suggests that it is already dead" (1981: 77)-I reflect on what effect photography might have on 
that which is "already dead", the grave. This investigation, in turn, inspires new metaphors for the representation of another object that is ostensibly "already dead": empire as a sociopolitical form.

\section{Spirits}

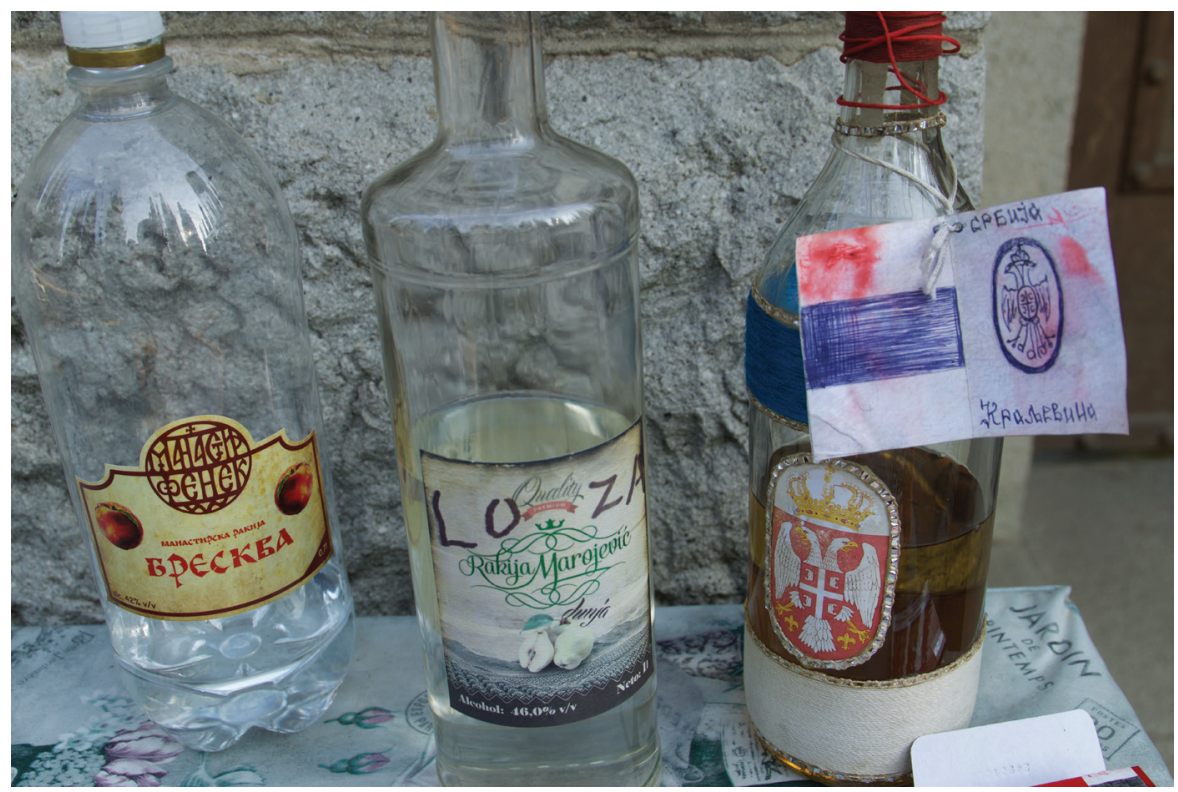

Figure 2: "Spirits".

A small table, draped in a cheap plastic tablecloth, abuts the rear of the Serbian Orthodox chapel in the Zeitenlik Allied War Cemetery in Thessaloniki, where some 20,000 Serbian, French, British, Italian, Russian, and Greek soldiers are interred, victims who fell on the Great War's Macedonian Front. Three bottles rest on the table, accompanied by several half-empty packs of cigarettes: offerings to the dead, to be consumed by the living. I pour a draught of breskovača, peach brandy, into a small glass and sip the stringent liquor. 
The brandy is a potent metaphor, as well as a potent potablemany spirits haunt this cemetery. Affixed to one bottle is a paper tag depicting a rough drawing of the heraldic, double-headed Serbian eagle. The drawing salutes "The Kingdom of Serbia", a polity with imperial pretensions that perished soon after the soldiers beneath my feet, at the end of World War I. Yet, like the spirits in my glass, the spirit of the bygone kingdom remains strong-I think of "Ovo je Srbija" ("This is Serbia"), the pop nationalist hymn by Serbian crooner Aca Lukas, which features the lyrics "The flowers have blossomed in Zeitenlik ... this is Serbia, the graves of soldiers speak of glorious times".

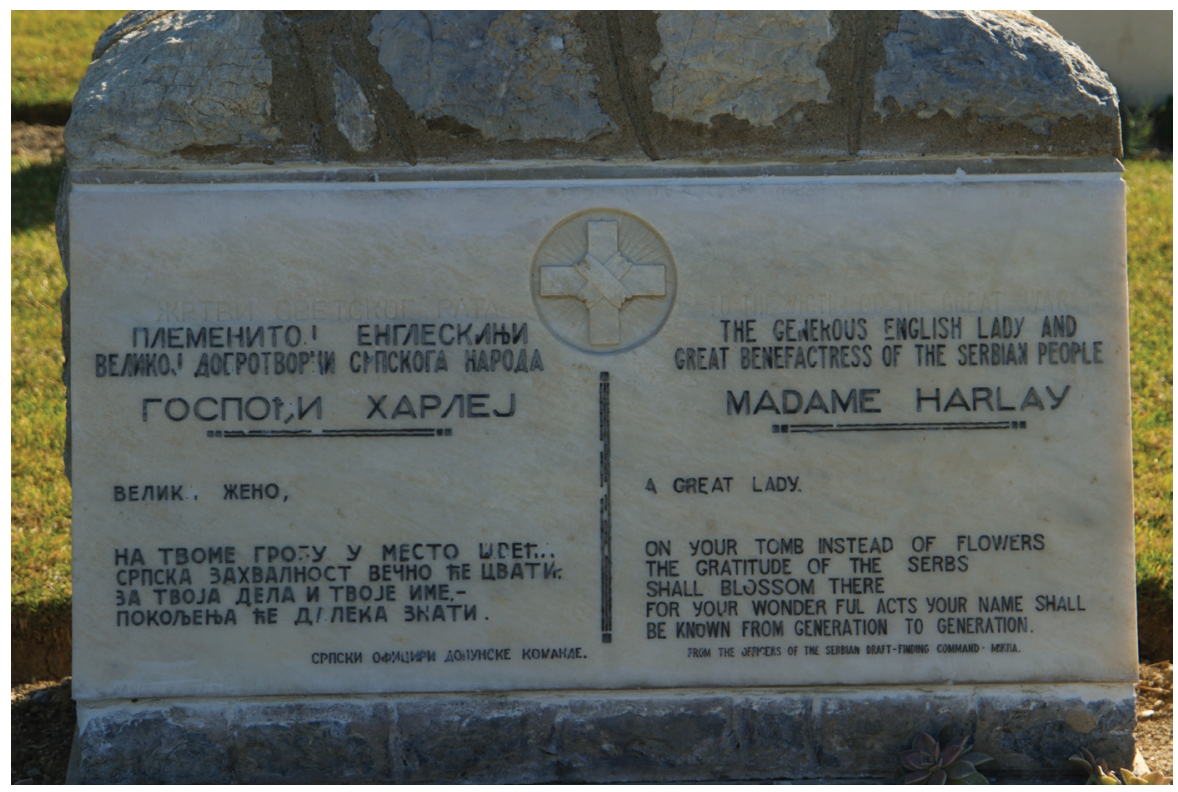

Figure 3: "Mobility".

1 A YouTube video of the song, accompanied by images of Zeitenlik and photographs from the Macedonian Front, is available at https://www. youtube.com/watch?v=S3ZR6A9qhCE (accessed 20 March 2019). More generally, Zeitenlik (Zejtinlik in Serbian) is a key site of memory in contemporary Serbia-for instance, see Rakocevic (1992). 


\section{Mobility and Stasis}

Like "Ovo je Srbija", the plot of graves surrounding the Serbian chapel suggests a homology between the past and the present: Through upkeep and pilgrimage, the dead soldiers of a kingdom that projected imperial might across the Balkans are equated with the nation-state of Serbia today. Elsewhere in Zeitenlik, such elisions are more difficult to uphold. A gravestone in the British section of the cemetery commemorates "A great benefactress of the Serbian people" in two languages, two scripts. Katherine Mary Harley was an English suffragette and nurse who, like Florence Nightingale before her, became an icon of selfless, heroic mercy far from home in the eastern Mediterranean. She was transferred to the Balkan theatre in 1915, where she conveyed wounded Allied soldiers away from the front in ambulance by the cover of night, often in violation of orders to the contrary. After her death in Monastir (Bitola) in 1917, the crown prince of Serbia and the highest-ranking British officer on the Macedonian Front were among the mourners in her funeral procession. ${ }^{2}$

Why is a Serbian memorial to an English nurse located in a Greek cemetery? To pose the question this way is to privilege nations and their states; an answer demands attention to the curious mobilities and geographic transpositions entailed by empires, especially empires at war. Such mobilities crystallize and endure in sepulchral spaces that resist the ebb and flow of time like boulders protruding from a cataract. The space of the cemetery is one of stasis and duress (Stoler 2016), which preserves the effects of imperial mobilities in concrete, marble, and granite forms.

2 Information about Katherine Harley is available on the website of the Commonwealth War Graves Commission at http://blog.cwgc.org/kathe erine-harley (accessed 20 March 2019). 


\section{Proximity I}

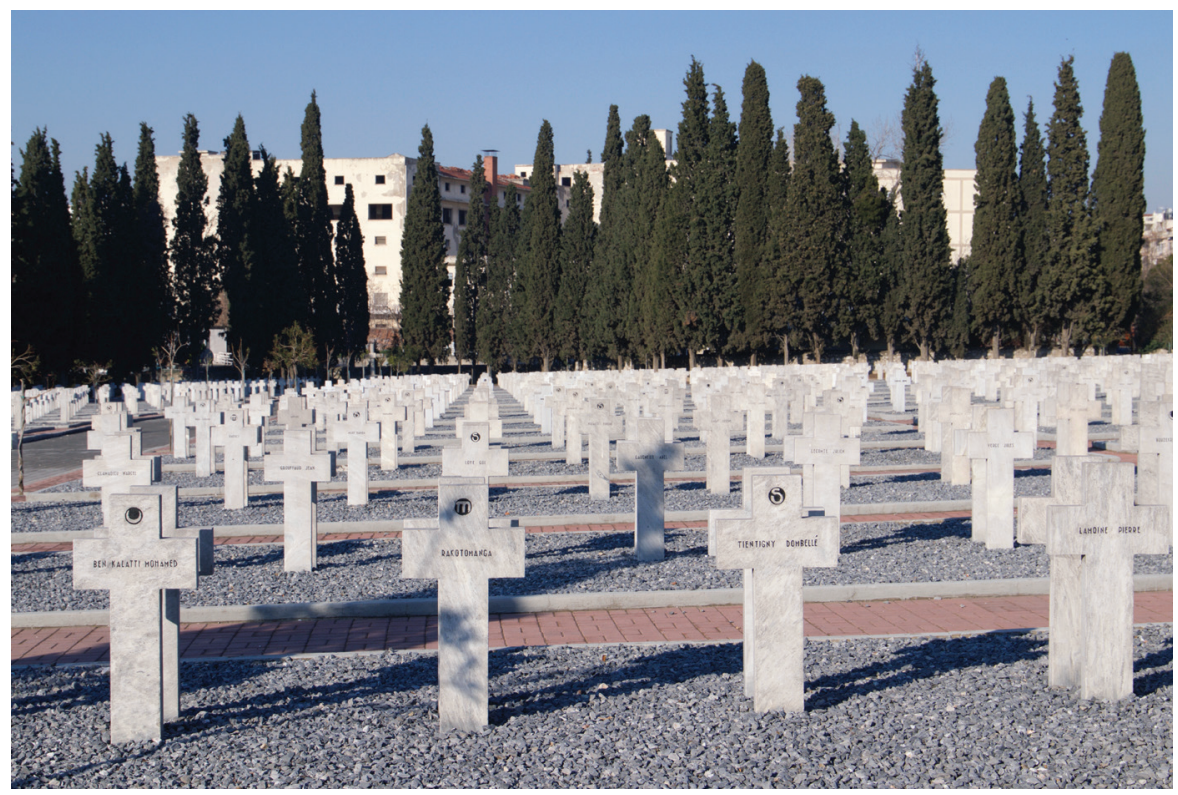

Figure 4: "Proximity l”.

Even more dramatic mobilities achieve sedimentation in another section of Zeitenlik. The largest plot in the necropolis is dedicated to some 8,000 French soldiers, whose identical tombstones register their occupants' fungibility as cannon fodder in life. Upon closer inspection, however, the French section reveals a principle of differentiation: the headstones of French colonial subjects, unlike soldiers from metropolitan France, display insignia that reveal the origins of their occupants. The cruciform graves of Muslim North African soldiers incongruently feature small, abstract crescent moons to denote their religious distinction. Cadets from South East Asia are commemorated with an "IC" (Indochina), those from Senegal with an "S", and those from Madagascar with an " $\mathrm{M}$ ". The names on many headstones also unsettle Franco-Catholic mortuary symbolism. At one point, I encounter four incongruous graves, side by side: Ben Kalatti 
Mohamed, a Maghrebi recruit; Rakotomanga, likely a Madagascan; Tientigny Dombellé, of Senegal; and Lamoine Pierre, probably from France itself.

Empires are not only mechanisms for mobility-they are also laboratories for proximity. Wartime entails violent, intimate closeness among individuals of disparate origins, languages, aspirations, and attitudes. Yet this proximity does not occur on a level political terrain. In Zeitenlik, only "French" soldiers, and thus the imperial power at large, are unmarked. The cemetery, like the Great War generally, must be understood in relation to the rapidly shifting political sands of its age, when imperial and national polities and identities underwent simultaneous fragmentation and concretization. Viewed in this light, Zeitenlik is not so much a fossil as a material archive of an era that uncannily refracts the concerns and dilemmas of the present.

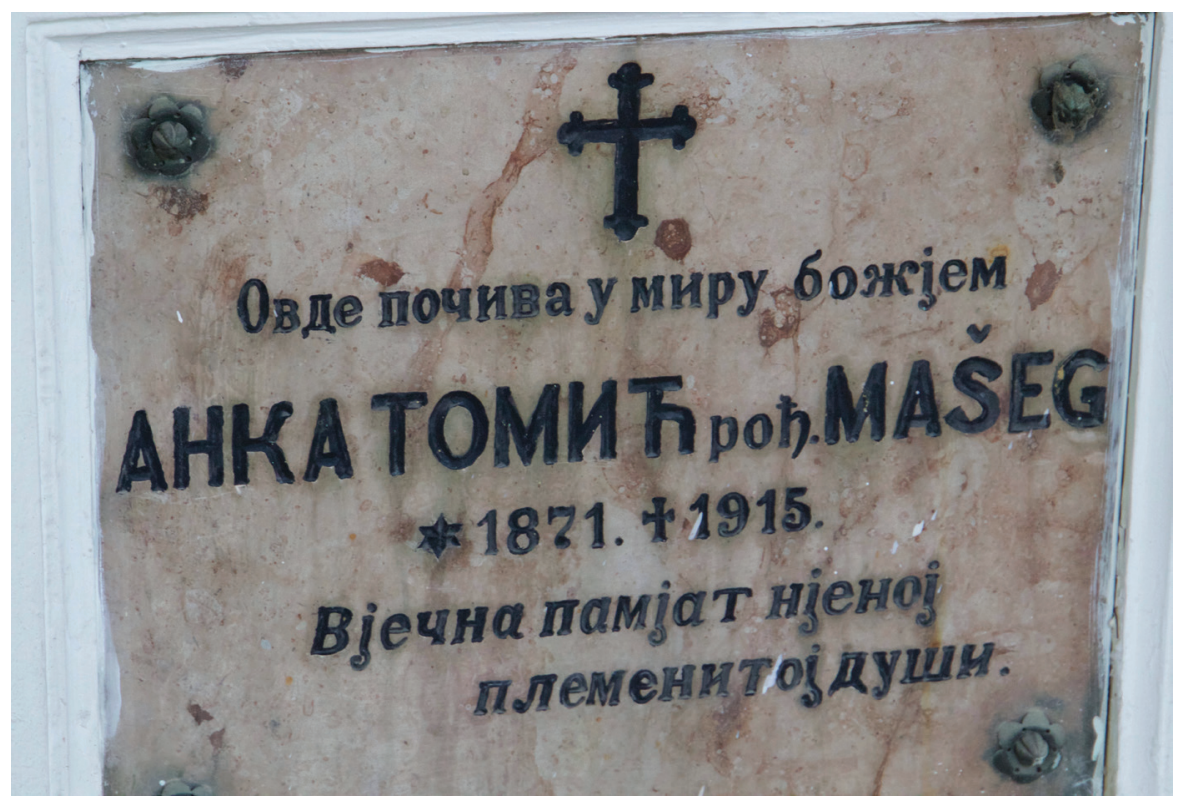

Figure 5: “Proximity II”. 


\section{Proximity II}

Not all forms of imperial proximity were matters of warfare. Several months after my visit to Zeitenlik, I spent an afternoon beneath the picturesque arcades of Zagreb's Mirogoj Cemetery, designed in the late nineteenth century by the local "starchitect" of the time, Hermann Bollé (Bartolić 1972; Damjanović 2013). Mirogoj's groundbreaking was a moment of mortuary centralization and secularization in the city. With a steeply rising population of both living and dead, Zagreb's municipal government elected to eliminate all existing graveyards, attached principally to local Catholic parishes, and to mandate burial for all of the city's denizens, regardless of confession or surname, in the single expanse of Mirogoj.

As an interdenominational city of the dead, Mirogoj hosts curious constellations of social formations that are no longer extant in contemporary Zagreb. One plaque in the south arcades enunciates a sociality that is almost unimaginable in contemporary Croatia. Anka Tomić was likely Orthodox, or at least married to an Orthodox man, as evinced by the Cyrillic script in which her name was inscribed. Yet she was probably not born into an Orthodox family: her maiden name, Mašeg, is inscribed in Latin script, suggesting a Catholic background. Certainly, religious conversion and interreligious marriage remain social and political facts in Zagreb and throughout the Balkans. Yet the politics of language and script in the wake of the disintegration of $\mathrm{Yu}$ goslavia has made such a bi-scriptural memorial, in which Latin and Cyrillic do not contradict each other, unlikely today. 


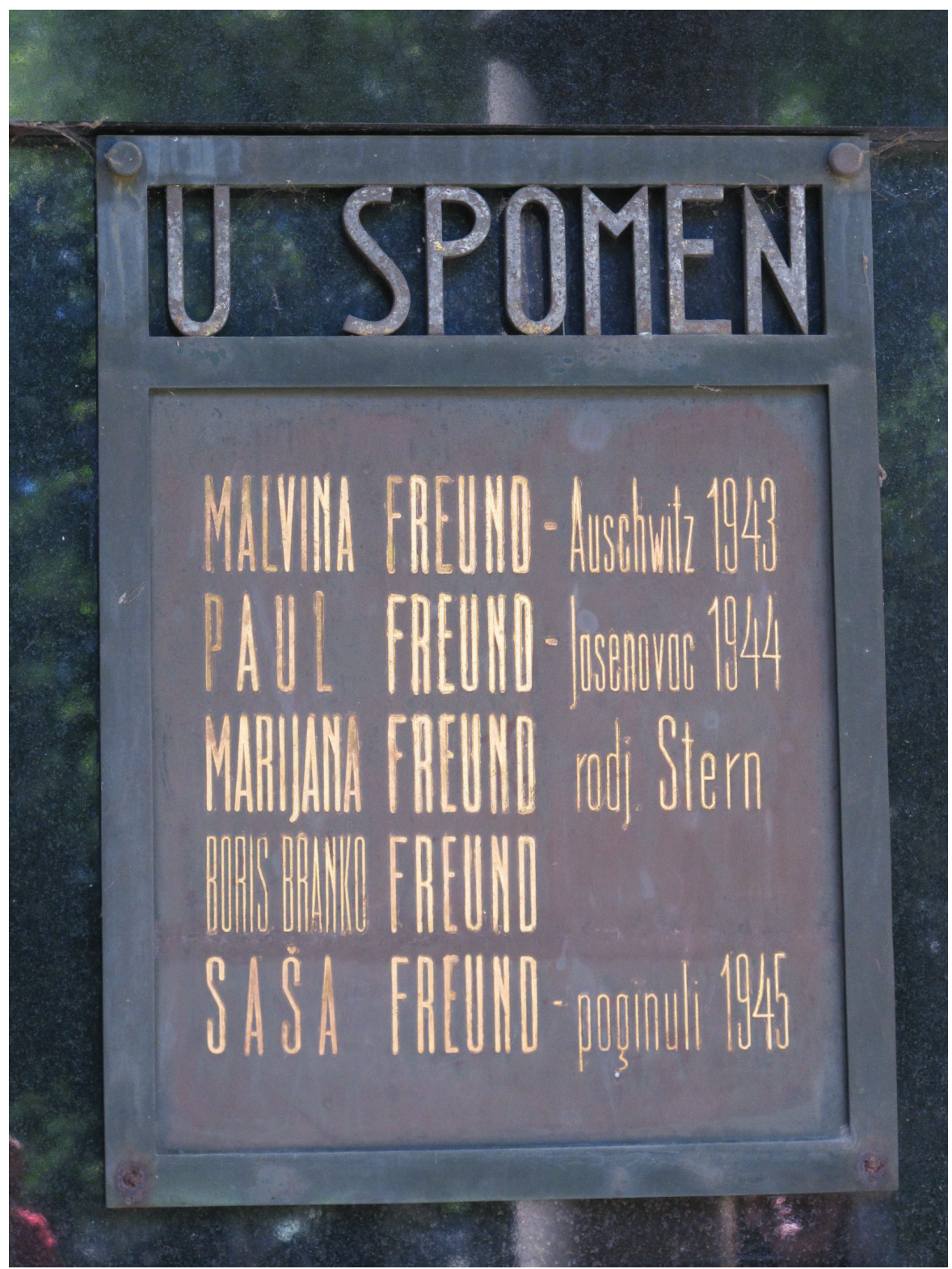

Figure 6: "Violence”. 


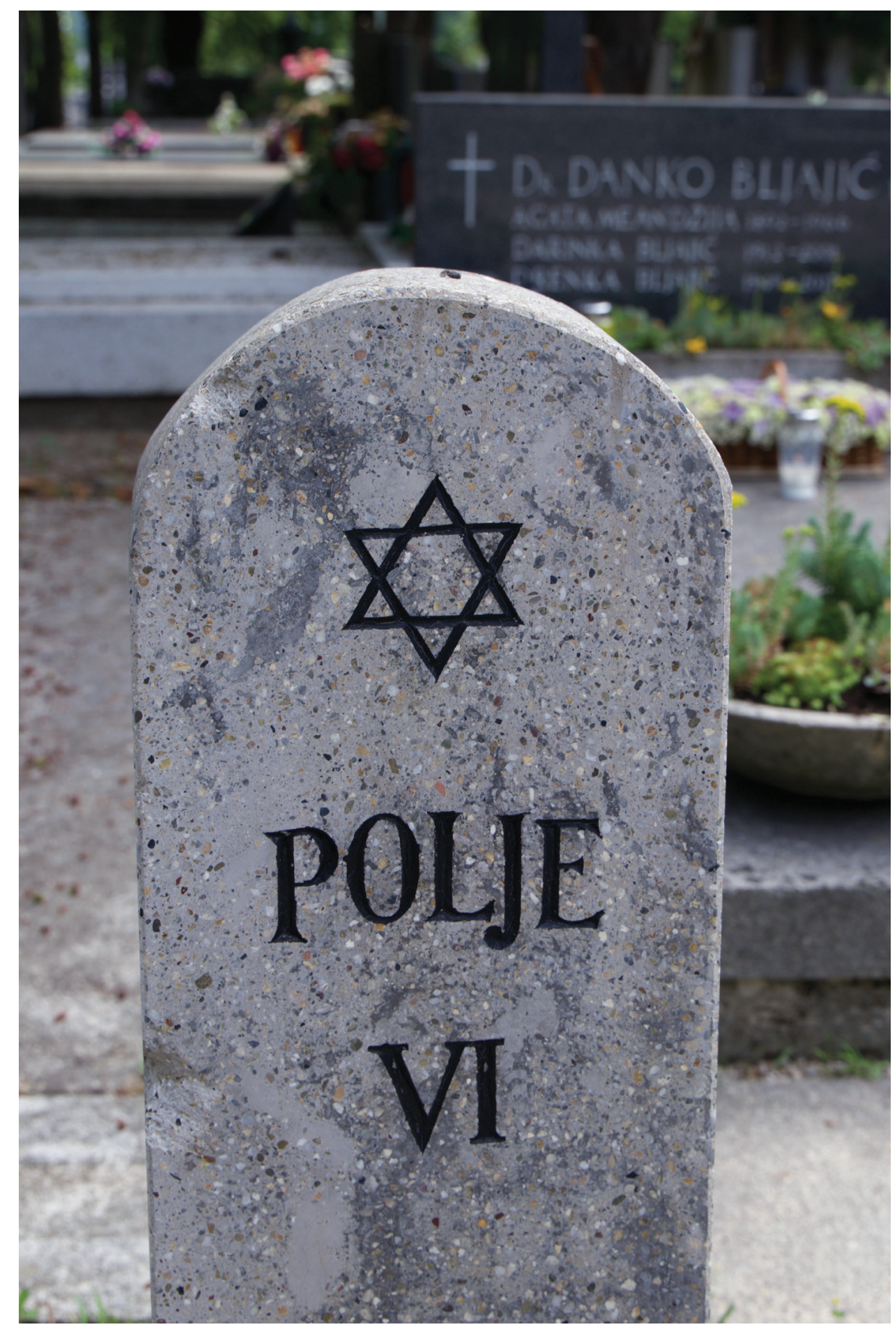

Figure 7: "Erasure”. 


\section{Violence and Erasure}

Violent death haunts Mirogoj. This is especially true in the Jewish section, where multiple memorials pay tribute to victims of the Holocaust. A funerary slab in the arcades records a legacy of violence: one member of the Freund family was murdered in Auschwitz, another in Jasenovac, the notorious concentration camp run by the fascist regime of the Ustaša during the brief wartime rule of the Independent State of Croatia, a Nazi auxiliary.

Mirogoj's Jewish graves are also the objects of a subtle form of material and symbolic violence: they are slowly disappearing. Just behind the marker that identifies the Jewish section of the cemetery are several unmistakably Catholic graves. Crosses have begun to replace the Star of David in Mirogoj for material reasons. The cemetery administration levies an annual fee to sustain each grave plot in Mirogoj; after several years of non-payment, a plot can be purchased anew. Most of the cemetery's Jewish graves entomb individuals whose descendants now reside far from Zagreb. They are therefore highly vulnerable to erasure due to financial delinquency.

\section{Patina}

Soon after my peregrinations in Mirogoj, I made a pilgrimage to another Habsburg-era cemetery in Croatia: the Imperial and Royal Naval Cemetery (Kaiserlich und Königlich Marinefriedhof) in Pula, once more commonly known as Pola, the principal military port for the Austro-Hungarian Empire. Habsburg multilingualism remains robust in the graveyard. The sign at the cemetery gates is trilingual, written in German, Croatian, and Italian; within are memorials in the languages of many of the inheritor nation-states of the empire. Wandering from these official 


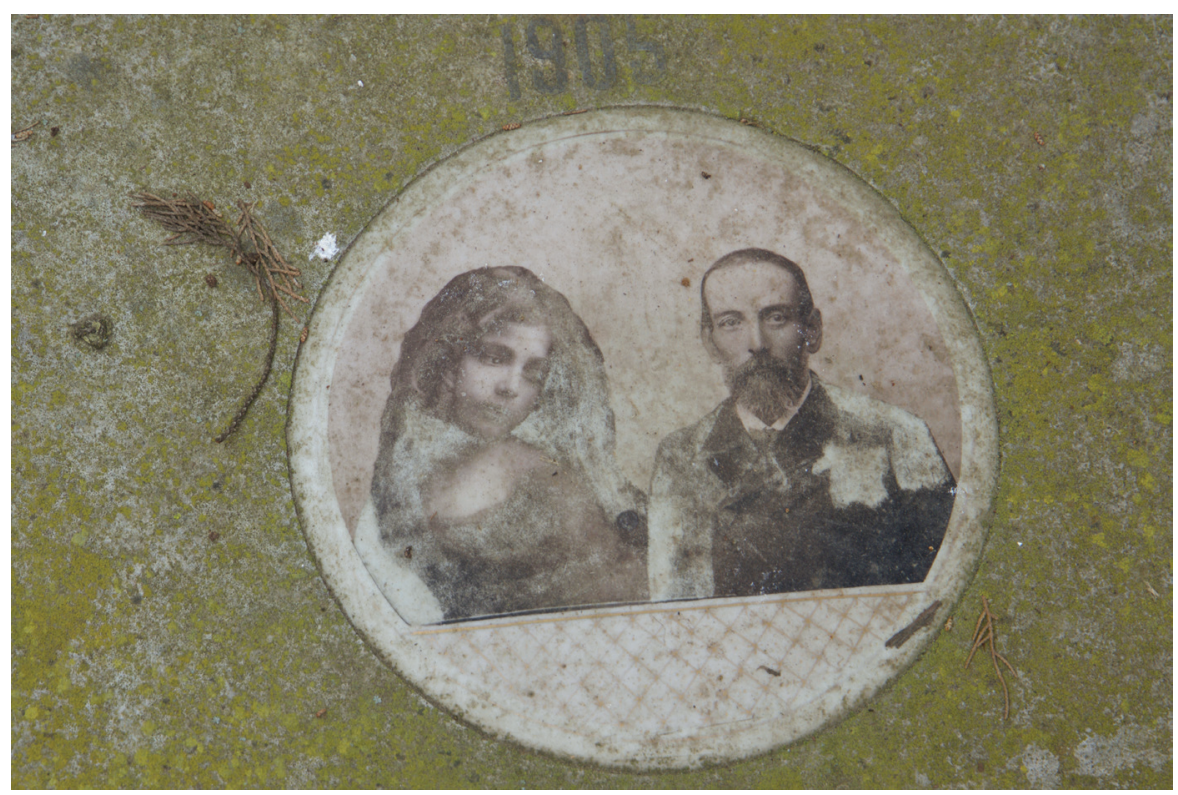

Figure 8: "Patina".

commemorative sites, my gaze is arrested by an evocative photograph affixed to a headstone. A bearded man in formal attire stares back at me placidly; his companion, a young woman, casts her eyes downward. The small circle of marble upon which their photographs are mounted is beaten and scratched, its surface rendered gritty by the salty marine air. Its patina (Dawdy 2016) of weathering enhances the effect of time's passage and heightens apperception of the gulf between eras and individuals alike.

If, as Barthes insists (1981: 77), photography renders that which it represents 'already dead', irrevocably past, an object rather than a subject, then what should one make of a photograph of a photograph that expresses the erosive, weathering processes of time? I would suggest an analogy: the photograph that I encountered in Pula is akin to memory of the empire in which the subjects it depicts lived. Far from "capturing" the history of bygone epochs in a quasi-objective fashion, we might seek out 
the battered patinas that their memories convey in the present, like the abrasions on a photograph of a dead couple whose very names have been expunged by a century of weathering.

\section{At an Angle}

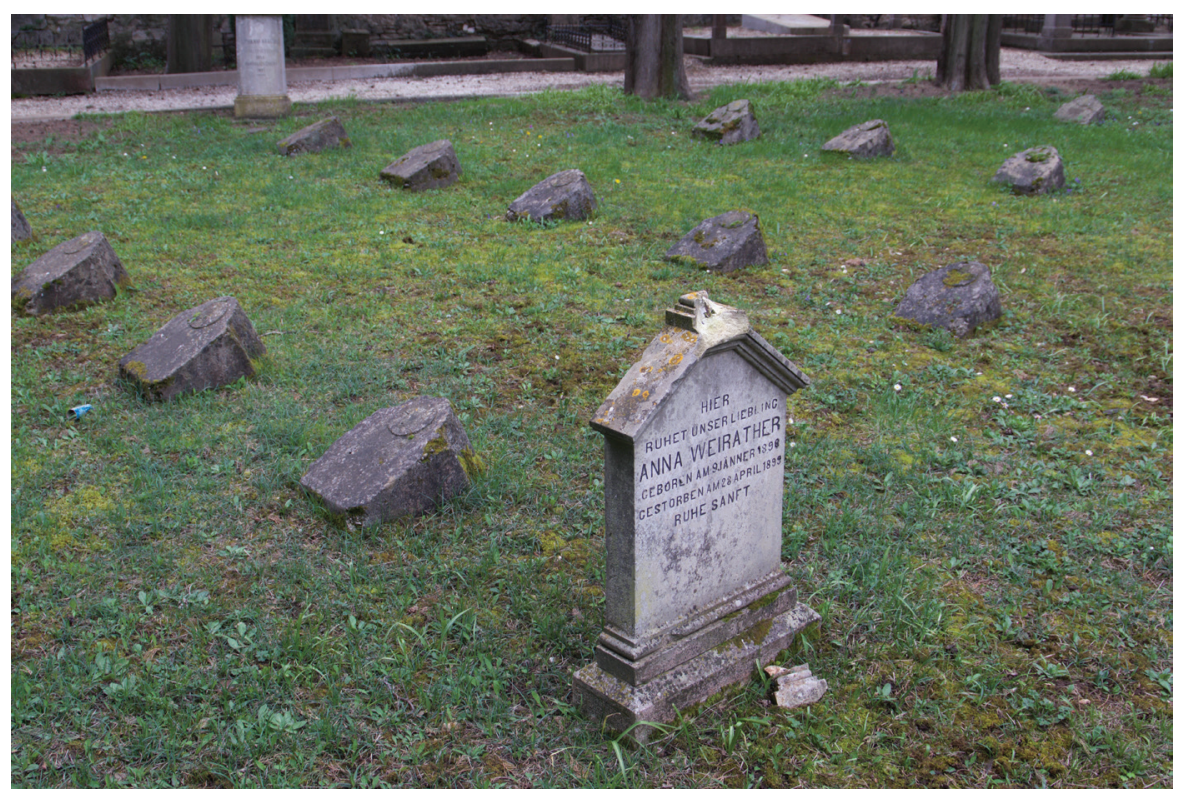

Figure 9: "At an Angle".

I had come to the Imperial and Royal Naval Cemetery to locate the graves of Bosnian Muslim sailors who died in the service of the Habsburgs, an aim that proved easier than I had expected: Geometry alone sufficed. The modest headstones of Bosniaks, small sandstone monuments overgrown by moss, are arranged in tidy rows pointing towards Mecca in the south-east. They stand at a sharp angle to the other tombstones in the cemetery, which are oriented along an east-west axis. 
The Naval Cemetery, like Zeitenlik and Mirogoj, is a partial, mortuary archive of forms of proximity that empires fostered. Today's naturalized categories of difference do not fully apply in these sepulchral, post-imperial spaces. Yet we should not romanticize forms of erstwhile proximity. Distinctions persisted, and communities, living and dead, were often awkwardly situated in relation to one another, at an angle.

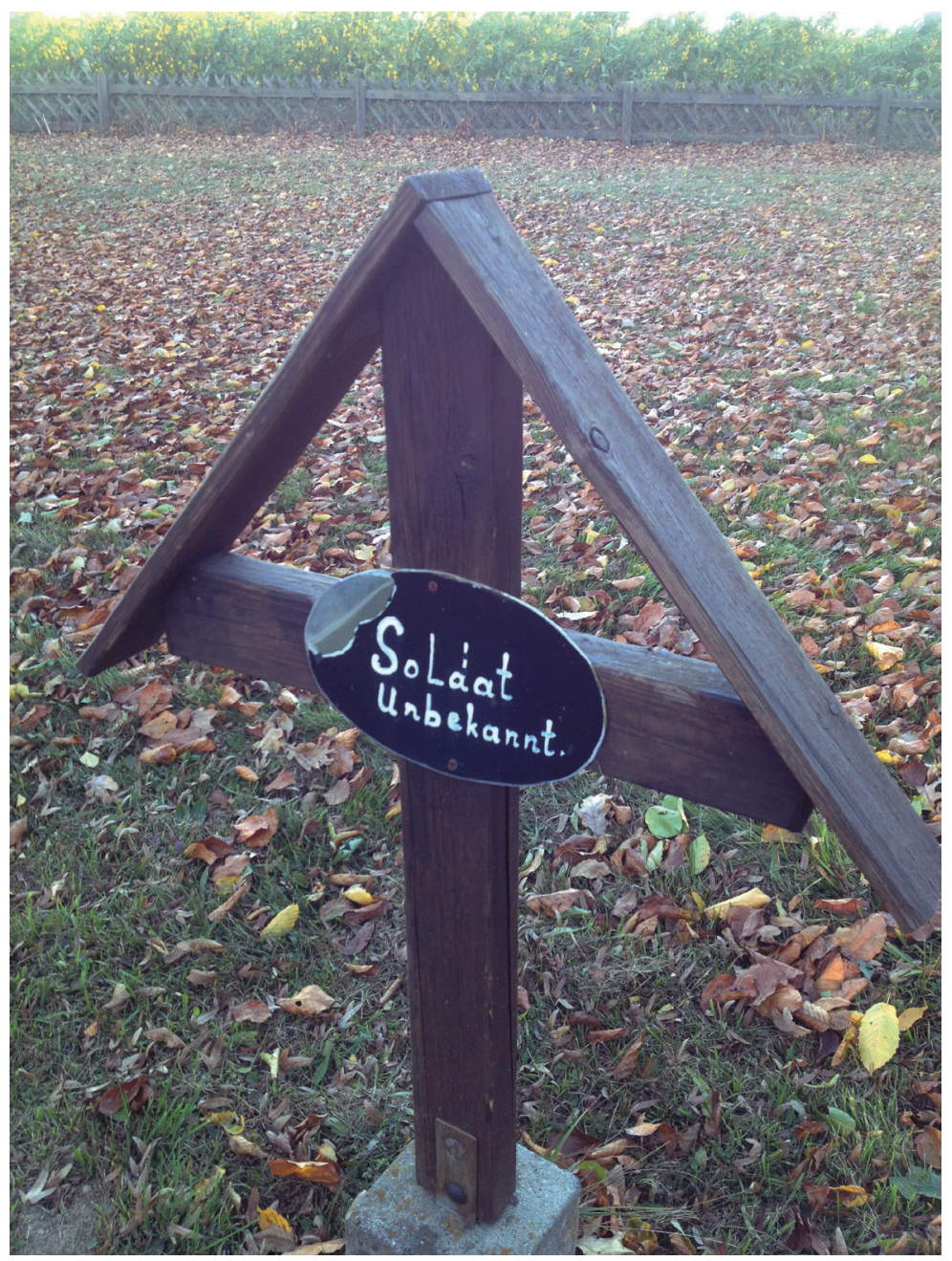

Figure 10: “Unknown”. 


\section{Conclusion: Unknown}

Located at the end of a dirt road that traverses corn and wheat fields, the Soldatenfriedhof in Lang, a hamlet in Austrian Styria, does not call attention to itself. The dead here resemble those in Pula in many ways - they embody the ethnolinguistic patchwork of the late Habsburg Empire. Here, one finds Bosniaks, Slovenes, Germans, Croats, Romanians, and others. Yet one common moniker on the wooden grave markers refuses the imperative of identification. It reads, simply, "Soldat unbekannt". Unknown soldier.

Tombs to unknown soldiers are, in fact, well known. Indeed, their proliferation after World War I enshrined a new figure of modern mass mourning (Wittman 2011). Nor should we assume that nothing can be known about "unknown" dead. The unknown soldiers in Lang's Soldatenfriedhof are unnamed in German and marked by crosses, gesturing to affiliations that the imagined national community of Austria today can easily absorb. Nonetheless, the grave of the unknown soldier might also point to the limits of knowledge in relation to histories of violence. Read in this manner, the graves of unknown soldiers in Styria offer powerful, salutary lessons to aggressive projects of memory, memorialization, and restorative nostalgia (Boym 2001). At a time when longing for former empires and neo-imperial adventures have grown more militant and robust, the unknown soldier insists on a measure of incommensurability between the past and the present, and recommends a strategically modest mode of historical consciousness based on this incommensurability.

\section{Acknowledgements}

I would like to thank Giulia Carabelli, Karin Doolan, Katarina Ivić-Doolan, Miloš Jova nović, Annika Kirbis, and Robert M. 
Walton III for their generous comments on this essay. Credit is due to Annika, as well, for introducing me to the Soldatenfriedhof in Lang, Austria.

JEREMY F. WALTON leads the Max Planck Research Group 'Empires of Memory: The Cultural Politics of Historicity in Former Habsburg and Ottoman Cities' at the Max Planck Institute for the Study of Religious and Ethnic Diversity (MPI-MMG) in Göttingen, Germany. He can be reached at walton@mmg.mpg.de.

\section{References}

Barthes, Roland. 1981. Camera Lucida. Reflections on Photography. Translated by Richard Howard. New York City: Hill and Wang. Bartolić, Stjepan, ed. 1972. Mirogoj Zagreb. Zagreb: Grafički zavod Hrvatske.

Boym, Svetlana. 2001. The Future of Nostalgia. New York: Basic Books.

Damjanović, Dragan. 2013. Arhitekt Herman Bollé. Zagreb: Leykam International.

Dawdy, Shannon. 2016. Patina. A Profound Archaeology. Chicago, IL: University of Chicago Press.

Rakocevic, Branko. 1992. Potupisi: Tragom mita po Grckoj Kajmakcalan - Krf - Zejtinlik. Belgrade: NIMEX.

Stoler, Ann Laura. 2016. Duress: Imperial Durabilities in Our Times. Durham, NC: Duke University Press.

Wittman, Laura. 2011. The Tomb of the Unknown Soldier, Modern Mourning, and the Reinvention of the Mystical Body. Toronto: University of Toronto Press. 